\title{
A Comparative Study of Interest Free Banking Practices in Ethiopia Private Commercial Banks Between Oromia International Bank and Oromia Cooperative Bank in Dire Dawa Districts
}

\author{
Biniyam Kebede Desta (MBA) \\ M \& N Research \& Business Consultant Plc. (G. Manager) in Dire Dawa, Ethiopia \\ Kokobe Meliese Bekele (MBA) \\ Graduated Rift Valley University Dire Dawa Campus, in Dire Dawa, Ethiopia
}

\begin{abstract}
The purpose of the study was to assess interest free banking practices in Ethiopia private commercial banks Oromia International Bank and Oromia Cooperative Bank in Dire Dawa. The researcher was used descriptive survey research design and multistage sampling techniques (both probability and non-probability techniques) to reach at the specific respondents. In this study was employed a descriptive and also inferential statistics such as such as independent-samples t-test and ordinal logistic (O logit) regression to see the effects of independent variables on dependent variable by using Statistical Packages for Social Sciences (SPSS) version 26 software. More specifically five interest free banking practices factors identified in the study; which are Awareness, Compatibility, Complexity, Perceived trust and Relative advantage with implementation of interest free banking (IFB) practices in private commercial banks. The Nagelkereke $\mathrm{R}^{2}$ indicates the model can for $63.3 \%$ of the variance in the implementation of interest free banking practices. The survey findings also revealed that interest free banking service it shows that "Complexity" have statistically insignificant and negative relationship with the implementation of interest free banking service. Thus, banks need to take these factors into account when developing their interest free banking services to ensure the success of their Islamic banking products and services. Banks need to enhance accessibility, profitability and service quality factors.
\end{abstract}

Keywords: Awareness, Compatibility, Perceived trust, Complexity, Relative Advantage, Implementation of IFB DOI: $10.7176 / \mathrm{EJBM} / 13-19-05$

Publication date:October $31^{\text {st }} 2021$

\subsection{Background of the Study}

Interest free banking is a banking system that compliance with Islamic Law "Shariah". The rules and practices under interest free banking are in accordance with the primary sources of Shariah Law. The growth of Interest free Banking partly reflects demand from Muslim population and non-Muslim clients for Interest free deposit facilities and fund management services which involve Shariah compliance (Wondwosen, 2018).

According to Franzoni and Allali (2018), quite apart from the conventional finance, Islamic finance is built upon five pillars which are the indispensable measurements of religious validity (Sharia Compliance) of any financial activity performed under the umbrella of Islamic finance. These fundamental pillars are prohibition of Riba (interest), ban on speculative elements in financial contracts (Gharar), Prohibition of gambling (mayser), ban on the use of trade and investment involving any element of prohibited asset or activity (Haram), profit and loss sharing principle and the imperative to have real assets underlying any given financial transaction.

Among these financial instruments accepting deposit, money transfer, bankers called sarrafeen or sayarifah, promissory notes (reqaah al-sayarifah), bills of exchange (suftaja), cheque (sakk) and treasury (Baytal-Mal) were common (Mohamad, et al., 2013; Alharbi, 2015). Suadiq and Ibrahim (2020) on the subject of adapting conventional financial system Muslim scholars' opinion fall into three groups. Scholars in the first group opined accessing conventional financial services is halal (permitted). Contrary to this, the second group of scholars argued accessing conventional finance is Haram (prohibited) but, it is also important. The third group argued that accessing conventional finance is necessary though riba (interest) is undoubtedly prohibited (haram).

The Ethiopian banking sector has expanded in the few past decades and benefit only some part of the community so that introducing interest-free banks which is the way to improve the poor and the disadvantaged segments of the society is a logical next step. As far as potential for interest free banking (Islamic bank) is concerned, the government facilitated the necessary legal framework about 8 years ago. The potential benefits of allowing Islamic banking include; decreased economic disparity between the rich and poor, better integration, and consequently accelerated economic growth (Mohamed Muhumed, 2012).

Government of Ethiopia can leap a step closer towards the fulfillment of the much appreciated dream of "Middle Income Country" by reforming its banking sector and allowing the establishment of Islamic Banks. 
Even if the developments of Islamic finance in the Ethiopia have taken place since the first individual and group initiatives surfaced in early 2008 years it is at developing stage. The past legal framework in Ethiopia does not permit full-fledged Islamic Banking which offers the owners of capital to share the profits made by the entrepreneur who comes up with investment projects, rather the National Bank of Ethiopia (NBE) issued a directive to banks allowing them to provide interest-free banking (Islamic banking) service using a separate window along with their other banking services to suit society's diverse financial needs.

The National Bank of Ethiopia's directive came into force in October 2011 about first Islamic Financial Institution in Ethiopia, However, the implementation of this banking system was started only in 2013 by few commercial banks like Oromia international bank S.C, Commercial Bank of Ethiopia and united bank S.C. Customers who are interested in the interest free banking are assured that they will obtain all those services that they would get from a fully-fledged interest free banking. However, the implementation part is not as speedy as the business persons would prefer, who would like to move immediately and get financing for their projects as quickly as possible because the newly established interest free banking must first collect enough deposits, since the principle does not allow them to finance Murabaha projects from the bank's conventional deposits. So, currently at Oromia international bank S.C out of above birr 5 billion deposit mobilized during the financial year 2013/2014 under review, 3\% or Birr 175 million(Ethiopian money) from total accounts of 8,819 maintained in 76 branches was mobilized through newly introduced bank product, Interest Free Bank Service.

The Interest Free Bank Window was commenced operation in mid of December 2013 which has contributed and promised a potential of differently mobilizing resources ahead of the Bank's time, the service being commenced on a limited number of branches only (Oromia international bank S.C Annual report 2013/14). In addition the commercial bank of Ethiopia starting launching interest free banking services at the end of October, 2013 and has attained 6,000 customers for its interest free banking service, with 100 million Birr (Ethiopian money) in savings from 23 interest free banking clients by the first week of May. Currently as the Commercial Bank of Ethiopia interest free banking performance document indicated at October 29, 2014 the total deposit of 364 million from each Wadiya Amanah, Qard, Mudaraba saving accounts are 282 million, 46 million and 36 million Birr respectively from the 145 bank branches and 23,686 customers. It also indicated as 92 million Birr approved for finance granted by the bank (Fortune report, May 18, 2014).

Starting from 2011 there is an improvement and development in IFB system in Ethiopia. Currently above nine banks have the license from National Bank of Ethiopia (NBE) and start promoting Interest Free Banking (IFB) service and accepting noninterest deposits but five of the conventional banks are involved in financing. The finance given by those banks are, Profit and loss sharing (murabah), a profit sharing joint venture (musharaka), a profit sharing agreement (mudaraba), supplying industrial products to clients order (istisna), a globally recognized mode of leasing (ijara) and other services (Wondwosen, 2018).

As per the Directives of National Bank of Ethiopia SBB/51/2011, all commercial banks that are licensed to engage in the Conventional Banking Business are privileged to engage in Interest Free Banking (IFB) business through the existing branch offices only after securing independent license for running the business, which is subject to fulfillment of some 10 to 11 terms and conditions set out thereof, among others, the directive also orders banks not to go past the maximum share of interest-free banking business in their consolidated balance sheet without prior approval from the National Bank. A violation of this could lead to the closure of an interest-free banking window. Preparation of separate financial reports, keeping all data and ensuring the segregation of activities from conventional banking are also some of the requirements set by the directive.

Subsequent to the issuance of the working directive, the NBE has granted the IFB service license to Oromia International Bank S.C on September 16, 2013. Same license is granted to the Commercial Bank of Ethiopia on September 17, 2013. Accordingly CBE using its 23 pilot branches and OIB using its 24 branch offices launched IFB operation on October 24, 2013 and December 16, 2013 respectively. On May 1, 2014, United Bank S.C. began providing IFB service and recently, Cooperative Bank of Oromia, Nib International Bank, Abay Bank and Wegagen Bank have joined the IFB business by giving depository products for the time being. However, Initially, Zemzem, a prospective new bank, requested to join the banking industry as a full-fledged interest-free bank, was unable to start operations as the directive requires that interest-free banking be given alongside conventional banking services (Tsion, 2017).

The main motivation of this study is therefore, to assess Interest Free Banking practices between private commercial banks in Dire Dawa Districts Ethiopia by using the case of two private commercial banks such as (Oromia International Bank and Oromia Cooperative Bank) operating in Dire Dawa.

\subsection{Statement of the Problem}

The empirical evidence shows that interest free banking have rapidly spreading and developing across the world. Studies in Ethiopia on IFB have been very few due to the infancy of the industry. For instance, Akmel (2015) studied about challenges and prospects of Islamic banking for resource mobilization in Ethiopian commercial 
banks. The study focuses on challenges and opportunities of IFB only on resource mobilization other challenges and opportunities are not well addressed.

On the other hand Yewubedar (2018) also conducted research on challenges and opportunities of interest free banking in case of commercial bank of Ethiopia northern district. The research concludes that lack of sheriah advisors boards, lack of awareness of customers regarding interest free banking, lack of confidence by customers, unavailability of the service in all branches are challenges of interest free banking operation.

A study conducted by Tsion (2017) the result of this study stated that lack of awareness by customers and difficulty to segregate fund for effective implementation of IFB service. The researcher concludes that the opportunities of interest free banking are more significant than the challenges. Numerous researches on the prospects, challenges, operational and risk aspects of Interest free banking studies Mohammed in (2012) in his work discuss the potential challenges as: lack of awareness, regulatory, supervisory and institutional challenges, lack of support, gap in research and development in Islamic studies, lack of qualified human resource as well as wrongful association with specific religion.

Most of the studies were conducted on challenges and opportunities of interest free banking services in Ethiopia. Researchers were identified and investigated several factors considered as relevant in influencing customers as well as attracting them towards the adoption of the Interest Free Banking Window Service (IFBW).

This, study, therefore, attempts to fill this research gap by investigating the major factors faced by service providers and users of IFB service provided by Ethiopian Private Commercial Banks through Interest Free Banking Window Service (IFBW). Thus, the researcher was to assess variables of the interest free banking practices there are some determinant factors such as Awareness, Compatibility, Complexity, Perceived trust, Relative advantage and Demographic factors (sex, age, educational status, religion and monthly income) in Ethiopian Private Commercial Banks. It is important to ascertain a comparative study of interest free banking practices by considering the case of two private commercial banks operating in Dire Dawa. Therefore, in this study the intention is not only to know to what extent customers are aware of IFB products and services but also to predict whether customers' awareness on IFB attributes affects the adoption of Interest Free Banking Window Service (IFBW).

\subsection{Research Questions}

1. What are the key factors (Awareness, Compatibility, Complexity, Perceived trust and Relative advantage) affecting the implementation of Interest Free Banking practices in Private Commercial Banks in Dire Dawa?

2. Do demographic factors (sex, age, educational status, occupation, religion and monthly income) affecting the implementation of Interest Free Banking practices in Private Commercial Banks in Dire Dawa?

\subsection{Objectives of the Study}

\subsubsection{General Objective}

The general objective of this research is to assess interest free banking practices between Private Commercial Banks in Dire Dawa Districts.

\subsubsection{Specific Objectives}

1. To examine the relationship of the key factors (Awareness, Compatibility, Complexity, Perceived trust and Relative advantage) with Implementation of Interest Free Banking Practices in Private Commercial Banks in Dire Dawa.

2. To find out how demographic factors (sex, age, educational status, occupation, religion and monthly income) affect the Implementation of Interest Free Banking Practices in Private Commercial Banks in Dire Dawa.

\subsection{Hypotheses of the study}

1. Awareness has a significant and positive influence on interest free banking practices in private commercial banks.

2. Compatibility has a significant and positive influence on interest free banking practices in private commercial banks.

3. Complexity has a significant and positive influence on interest free banking practices in private commercial banks.

4. Perceived trust has a significant and positive influence on interest free banking practices in private commercial banks.

5. Relative advantage has a significant and positive influence on interest free banking practices in private commercial banks.

6. A demographic factor (sex, age, educational status, occupation, religion and monthly income) has a 
significant and positive influence on interest free banking practices in private commercial banks.

\subsection{Significance of the Study}

The significance of the study is a comparative study of interest free banking practices between Private Commercial Banks in Dire Dawa Districts. The findings of the study will have theoretical and practical contributions. On the practical side, this study will help to acquire knowledge and practical experience to the bank policy and decision makers, bank managers, to identify how key factors (Awareness, Compatibility, Complexity, Perceived trust Relative and Advantage) affects the implementation of interest free banking practices in private commercial banks so as to make a decision. Theoretically, the findings of this study will fill an important gap and serve as a reference material and initiate other interested researchers as a starting point to carry out more extensive studies in the area.

\subsection{Limitations of the Study}

There has not been much literature developed in the Ethiopian context which again limits researcher's endeavor to frame the study in the theoretical and conceptual framework. The study will apply a quantitative research method and also the sampling was applied by using only non- probability sampling technique. When compared to the largeness of the target population, the researcher resorts to a smaller sample size. Even if broader research that encompasses all privet banks will give a more holistic view on the study; however, due to time and financial constraint the study is delimited geographically, conceptually and methodologically. The study was also limited only to the pieces of information that the respondents were unwilling due to Covid-19 pandemic disease. It is limit to the respondents' capability to answer such questions. This study was conducted in Oromia International Bank and Oromia Cooperative Bank in Dire Dawa and may not be generalizing to other Private Commercial Banks and Public owned Commercial Bank of Ethiopia in Dire Dawa.

\section{LITERATURE REVIEW}

\subsection{Factors of Interest Free Banking Practices}

\subsubsection{Customers Awareness}

A new idea does not go beyond the knowledge function, if sufficient knowledge is not obtained to become adequately informed so that, persuasion can take place (Kotler \& Amstrong, 2001; Rogers, 2003). On the other hand, in an age of information and "innovation overload" (Herbig \& Kramer, 2004) in which bank new products are continuously being introduced, many new products providers are extremely conscious of the need to provide consumers with as much information as possible about their product to make customers aware because new products require effective communication. Customers awareness have been tested as one of the key variable and positively influence customers attitude in numerous studies specifically in the area of on-line banking, internetbanking and self- services technology adoption (Gerad et al., 2003; Gholami et al., 2010; Daud et al., 2011; Hanafizadeh \& Khedmatgozar, 2012; Agarwal et al., 2009). However, limited studies have investigated on customers' awareness in the area of Islamic banking adoption. Most of these studies, include Metawa \& Almossawi (1998); Okumus (2005); Bley \& Kuehn (2004); Hamid \& Nordin (2001); Naser, et al., (1999); Haron, et al., (1994); Khattak \& Rehman (2010); Saini et al., (2011); Ahmad \& Haron (2002) indicates that consumers are aware of existence of Islamic banks.

However, they are unaware regarding the use of specific Islamic method of finance or low usage rate and could not differentiate between Islamic and conventional banks ${ }^{e e}$ financial products and services because of Islamic banks have not done enough in educating their customers and promoting products and services appropriately. Adoption is the acceptance and continued use of a product, service or idea.

\subsubsection{Perceived Complexity}

The degree to which a product, idea or innovation seems to be difficult to understand as well as use is main concept of complexity (Rogers, 2003). Actually, complexity explains required level of physical or mental efforts which is needed by individuals for adopting and continues usage of a particular innovation (Nor et al., 2010). An innovation with substantial complexity requires more technical skills and needs greater implementation and operational efforts to increase its chances of adoption (Wang et al., 2007). In addition, it has been hypothesized and proved as complexities have a negative connection with rate of adoption (Rogers, 1995; Ndubisi and Sinti (2006); Lee et al., 2011; Corrigan, 2012) due to the fact that complexity of an innovation, idea or product can act as an inhibitor for its implementation in successful way (Wang et al., 2010). In contrast, a study by Tan and Teo (2000) in Singapore confirmed that complexity as one of perceived attributes of innovation characteristics does not have any noteworthy impact on adoption of internet banking. In this study perceived complexity of Interest free financial products and services is observed from whether it requires mental efforts which is needed by individuals for understanding and adopting it and whether the terms and concepts the bank used is difficult for adopting. 


\subsubsection{Perceived Compatibility}

Compatibility refers to the degree to which an innovation, idea or product is known to be consistent with past related experience, current values (religious and ethical values basis) and different needs of potential adopters (Rogers, 2003). An innovation is more likely to be adopted when it is compatible with social system norms as well as values (Tornatzky \& Klein, 1982; Anuar et al., 2012b). Furthermore, previous studies widely have indicated that compatibility positively influencing adoption and as one of perceived attributes of innovation characteristics in concept of beliefs and past experiences as well as values affect innovation adoption in multiple different context (Tung et al., 2008; Norazah, 2006; Beiglo and Zare, 2011; Wu et al., 2007; Hernandez and Mazzon, 2007; Arts et al., 2011; Giovanis et al., 2012; Papies and Clement 2008; Elahi and Hassanzadeh, 2009). As such, in regards to banking experiences and practices, the Ethiopian banking consumers have already possess banking habits from the long operating conventional banks and Interest free banking functions and operations are new to them. Therefore, this study seeks to examine compatibility concerning IFB in the context of consumers ${ }^{\text {ee }}$ felt need for banking based on their religious and ethical values.

\subsubsection{Perceived Trust}

Trust has been described as interest of people to be vulnerable linked to other people or part actions (Mayer et al., 1995). Actually, trust is identified as extensively accepted predictor of adoption in different studies and scholars constantly have indicated that trust positively influence adoption of different type of innovation, products and services therefore, it should be taken into consideration by the Service providers; if consumers do not feel secure they will be reluctant to use the services (Gefen, 2000, Gholami et al., 2010; Sohail and Shanmugham, 2003; Suh and Han, 2003; George, 2002; Liu and Wu, 2007; Kim et al., 2009). As Cerf (2010) asserted, trust is essential to most human transactions so banking should show trustworthiness by keeping their promise to determine how well-intentioned and truthful banking is. Farah and Higby (2001); Sipior et al., (2004) also indicated as the success of Innovative products and services adoption is highly related to consumer's trust; Nitin Nayak et al., (2014) specified as Trust between the customers and the service provider is very Important to deal with in better way. This paper also intend to investigate the role of trust in context of Interest free financial products and services from customers' point of view relating to whether performance of the bank is properly Shariah based service.

\subsubsection{Relative Advantage of Interest Free Banking}

Relative advantage has been designed to reflect perceptions of customers which all or certain qualities of the proposed innovation can offer incremental value to its potential adopter comparing with present available options (Rogers, 2003; Flight et al., 2011). Rogers $(1995,2003)$ have indicated that relative advantage can be explained as economic profitability, discomfort decreasing, saving in time and effort, low initial cost, social prestige, and/or other potential benefits that possible user would receive by applying the current innovation. Potential adopters want to know, if the new idea is better than an existing one. Besides, several scholars have found relative advantage to be one of the best predictors of an innovation's rate of adoption (Brown et al., 2003; Tan and Teo, 2000; Hsu et al., 2007; Tung \& Rieck, 2005; Thambiah et al., 2011b; Gerrard and Cunningham, 2003).

\subsection{Empirical Literature Review}

Interest free banking is an infant stage in Ethiopia banking industry is not a well-studied area, through; few studies were conducted on the attributes of IFB. Mohammed (2012) has studied the "Prospects, Opportunities and Challenges of Islamic Banking in Ethiopia" and his work has identified the potential challenges as: lack of awareness, regulatory and supervisory challenges, institutional challenges, lack of support and link institutions, gap in research and development in Islamic studies, lack of qualified human resource as well as wrongful association with specific religion and the global terrorism. On the other hand Teferi's (2015) study about the "Contribution of IFB to economic development and its prospect in Ethiopia". He assessed the contribution of the inclusion of the Muslim population in the banking (financial system) to the economic development and GDP growth.

Another study by Debebe (2015) has conducted a study on "Factors Affecting Customers to Use Interest Free Banking in Ethiopia". The study is centered on "customer" intention and willingness to use interest free bankinge". The result showed that perceived relative advantage, perceived compatibility, customers"e level of awareness and subjective norm have a significant positive effect on the attitude towards interest free banking in commercial bank of Ethiopia. This study is about effect assessment on the attitude towards IFB usage which does not address the factors determine on implementation of Interest free Banking products and service in Ethiopian. Akmel (2015) the study focused on assessing challenges and prospects of Islamic banking service in resource mobilization efforts in three commercial banks in Ethiopia. This study is more concentrated on the challenges in the banks' operational activity of resource mobilization. The research made by Kerima (2016) finds out the following challenges: lack of capacity to deliver IFB product at full rage, lack of awareness of customer about IFB products, lack of trust and confidence of customers, inadequate marketing and promotion, 
double taxation, nature of IFB products, unavailability of IFB products in all of its branches and the IFB being delivered in a Window model. Accordingly, the following recommendations were forwarded by her aggressive promotion and marketing campaign about IFB products, provide sustainable and continuous training to build the capacity of the manpower, the bank shall increase accessibility of its products with the expected services attached to the products, the bank has to have Sharia'h Advisor, give the required attention and focus for the business and the bank has to be transparent in its IFB business undertaking, in addition to these NBE directives, tax and ECX law shall include exceptions for IFB business.

The recent study by Abraham (2017) on determinate of customers' intention to use interest free banking products and factors affecting employees' product knowledge in the context of commercial bank of Ethiopia and the result show that except knowledge, all the other variables: attitude, social influence, perceived financial cost and religious belief have significant effect on IFB use intention. Furthermore, chi-square test was used to analyze the association between selected demographic factors and IFB usage intention. The findings of this study have shown that, except for educational level, all other demographic factors found to have an insignificant on IFB adoption intention.

The reviewed literature was on different aspect of Interest free banking mainly about concept and practice of interest free banking. It was highlighted that the Ethiopian population is one of the fastest growing populations in the world and the Muslim community was a great proportion of that growing population. Though the introduction of interest free banking in the county was found to be a very great achievement for the development of the country's economy however, few researches had given attention to understanding this concept in the Ethiopian context. It was found out that the few researches dealt with factors affecting consumers to use IFB, this study provides information relevant to the understanding of the customers' side.

There is, no study so far has tested by employing ordinal logistic ( $\mathrm{O}$ logit) regression modeling to see the effects of independent variables on dependent variable. This study therefore intends to investigate the factors affecting the implementation of Interest free banking practices between Private Commercial Banks in Dire Dawa Districts. Hence the present study is expected to fill that gap by giving first-hand information on such as an important topic.

\section{RESEARCH METHODOLOGY}

\subsection{Research Design}

The researcher was used descriptive survey research design, which is a fact finding enquiry that explains phenomena as they exist at that moment in time. Survey involves asking structured questions to a representative cross section of the population at a single point in time.

\subsection{Target Population}

The study target populations were account holders of IFB from two private commercial banks such as (Oromia Cooperative Bank and Oromia International Bank) operating in Dire Dawa. This sample was used to select from Oromia Cooperative Bank selected branch such as Connele branch Afetisa branch and Sabiyan branch $(7,085$, 14,950 and 13,700 respectively) and from Oromia International Bank selected branch such as Connele branch Afetisa branch and Sabiyan branch (3,270, 5,476 and 3,000 respectively) customers (account holders) of IFB data published annually (2020).

\subsection{Sample Size and Sampling Technique}

In this study was employed sample size, the researcher based on the document found a list of the population from selected Oromia Cooperative Bank and Oromia International Bank annually report data (2020). The sample size selection was considered as representative of some selected 4,497 customers from two private banks in DDA. Population is large enough to allow for precision, confidence and general liability of the research findings. To ensure the representativeness of the sample, for large population size Cochran (1963) used the following formula: Where: $\mathrm{n}=$ Sample size $397 ; \mathrm{N}=$ population size 47,$483 ; \mathrm{Z}=\mathrm{Z}$ statistical for a level of confidence $(95 \%)$ Confidence interval equal to $1.96 ; \mathrm{P}=$ expected population (in proportion of one) $(0.5)$; $\mathrm{d}=$ precision (in population of one) (5\%). The study was involve a sample size total of 397 populations were account holders of IFB from two private commercial banks such as (Oromia Cooperative Bank and Oromia International Bank) to gather information from the respondents.

This study used multistage sampling techniques (both probability and non-probability techniques) to reach at the specific respondents. The same technique was employed by previous researches (Debebe, 2015; Kerima, 2016; Abraham, 2017, cited in Nobele 2019). Therefore, the researcher was used Stratified Random Sampling Technique to draw the sample elements.

\subsection{Methods of Data Analysis}

In this study, both descriptive statistics and inferential statistical analysis models were applied in order to analyze 
and understand the effect of interest free banking practices between Private Commercial Banks in Dire Dawa Districts. Data was analyzed with the help of Statistical Package for Social Sciences (SPSS) Software version 26.0. Program to help generate statistical analysis and present the data through the statistical techniques was presented in tables.

\subsection{Model Specification Ordinal Logistic Regression (O logit)}

In this study was used Ordinal Logistic Regression (O logit) model. Ordinal logistic (O logit) regression analysis is a technique used to analyze the association between a single DV and several IVs (Gujarati \& Porter, 2010). Ordinal logistic regression is a generalized linear modeling technique that may be used to model a single response variable which has been recorded on at least an interval (ordinal) scale. Independent Variables such as Awareness, Compatibility, Perceived trust, Complexity, and Demographic factors (sex, age, educational status, marital status, religion and monthly income) and Dependent Variable were Implementation of Interest Free Banking Practices (IIFBP) in Oromia Cooperative Bank and Oromia International Bank. According to Gujarati (2004) the model is represented as the following function. Generally, we can express the ordinal logistic model for $\mathrm{k}$ predictors with $\mathrm{P}-1$ levels response variable as:

$$
\frac{\ln (\mathbf{\Sigma} p r(\mathbf{Y} \leq \mathbf{j} \mid \mathbf{x})}{1-\operatorname{\Sigma pr}(\mathbf{Y} \leq \mathbf{j} \mid \mathbf{x}))}=\boldsymbol{\alpha j}+\boldsymbol{\beta i}, \mathbf{1}
$$

$\log (\boldsymbol{I I F B P} * \boldsymbol{i})=\boldsymbol{\alpha} \boldsymbol{j}+\boldsymbol{\beta} 1$ Awareness $* \boldsymbol{i}+\boldsymbol{\beta} \mathbf{2}$ Compatibility $* \boldsymbol{i}+\boldsymbol{\beta 3}$ Perceived trust $* \boldsymbol{i}+\boldsymbol{\beta} 4$ Complexity $* \boldsymbol{i}+\boldsymbol{\beta 5}$ Relative Advantage *i+ $\boldsymbol{\beta} 6$ Demography $* \boldsymbol{i}+\boldsymbol{\varepsilon} * \boldsymbol{i}$

Where: IIFBP* $\mathrm{i}=$ is the Customer of IFB respondent $\mathrm{i}(\mathrm{i}=1,2,3 \ldots \ldots)$,

$\boldsymbol{\alpha} \mathbf{j}=$ represents Constant term

$\mathbf{i}=$ represent each respondent whose response will be used for analysis

$\boldsymbol{\beta} \mathbf{j}=(\mathbf{j}=1,2,3, \ldots 11)$ are logistic regression coefficients to be estimated and,

$\mathbf{\varepsilon i}=$ random errors which are assumed to be independent.

\subsection{Reliability of the Research Instrument}

Reliability test is used to obtain stability and consistency of measurement where replication obtains same results over different circumstances if same method is used. Cronbach's alpha Awareness 0.734, Compatibility 0.755, Complexity 0.739 , Perceived trust 0.756 and Relative advantage 0.776 . Reliability test was conducted by use of Cronbach's alpha. Alpha values ranged from 0.734 to 0.875 , thus indicating an acceptable level of reliability. This implies that the instrument was reliable for use in data collection.

\section{RESULTS AND DISCUSSIONS}

\subsection{Response rate}

Response rate out of the 397 questionnaires administered, 285 were returned fully completed, giving a response rate of $72 \%$. Out of this sample, 112 questionnaires were not returned which will make the non-response rate of $28 \%$. Therefor the response rate is enough to carry out the analysis and which was considered appropriate for the study. According to Zikmund et.al., (2010) note that a response rate of over fifty percent (50\%) is adequate for analysis, sixty percent $(60 \%)$ good while seventy percent $(70 \%)$ and over to be very good enough. High response rate enhances validity and importance of the findings. Hence, since the overall response rate in this study was eighty percent $(72 \%)$, it was regarded good and adequate for further analysis.

\subsection{Descriptive Statistics of Overall Implementation of Interest free banking}

Descriptive statistics involved computing the mean of the statements that reflect on the research questions. For easier interpretation of the results of the study, researcher refers to the interpretation of scores $1.00-1.80=$ worst, $1.81-2.60=$ low, $2.61-3.40=$ enough/moderate, $3.41-4.20=$ high and $4.21-5.00=$ very high (Bahri et al., 2012; Munizu, 2013; Sugiyono, 2008). Respondents opinion Overall Implementation of Interest free banking was discussed with respondents and their reaction analyzed and presented in Table 1 illustrates the distribution of descriptive statistics the employees' views in the form of frequency, percentage, mean and Std. Deviation. 
Table 1: Descriptive Statistics of Overall Implementation of IFB

\begin{tabular}{lcc}
\hline Level of agreement & Frequency & Percent \\
\hline Very low & 15 & 5.3 \\
Low & 55 & 19.3 \\
Moderate & 62 & 21.8 \\
High & 70 & 24.6 \\
Very High & 83 & 29.1 \\
\hline Total & 285 & 100.0 \\
\hline Mean & \multicolumn{3}{c}{3.53} \\
\hline Std. Deviation & \multicolumn{3}{c}{1.240} \\
\hline
\end{tabular}

The findings in table 1 above, the respondents were asked that to what extent do you agree that the provision of interest free banking service the survey results reveal that the majority of respondents $83(29.1 \%)$ were very high and who high $70(24.6 \%)$, while $62(21.8 \%)$ moderate, $55(19.3 \%)$ low and $15(5.3 \%)$ very low. This was collaborated with a high mean (3.53) and slightly low standard deviation at (1.14) indicating that the variation between the respondents is high.

\subsection{Inferential Statistical Analysis}

The aim of inferential statistics is to approximate and make inferences about statistical characteristics of populations. Inferential statistics are techniques that allow the use of samples to generalize the populations from which the samples were drawn (Firtle, 2013). The methods of inferential statistics are majorly the estimation of the parameter(s) and the testing of statistical hypotheses. It describes the data with making inference or conclusion and summarizing sources of numerical data in to meaningful form. In this study were employed independent-samples t-test, and ordinal logistic (O logit) regression to see the effects of independent variables on dependent variable by using Statistical Packages for Social Sciences (SPSS) version 26 software.

\subsubsection{Independent Sample T-Test result}

An independent-samples t-test is used to compare the mean score for two different groups (Oromia International Bank and Oromia Cooperative Bank) to investigate if there is a significance difference between the mean scores of interest free banking practices in two groups. The study was to assess Awareness, Compatibility, Perceived trust, Complexity and Relative Advantage with implementation of interest free banking practices in private commercial banks.

Table 2: Group Statistics between Private Commercial Banks

\begin{tabular}{|c|c|c|c|c|c|}
\hline Variables & Banks & $\mathbf{N}$ & Mean & $\begin{array}{c}\text { Std. } \\
\text { Deviation }\end{array}$ & $\begin{array}{c}\text { Std. Error } \\
\text { Mean }\end{array}$ \\
\hline \multirow[t]{2}{*}{ Gender } & Oromia International Bank & 57 & .39 & .491 & .065 \\
\hline & Oromia Cooperative Bank & 228 & .65 & .477 & .032 \\
\hline \multirow[t]{2}{*}{ Age } & Oromia International Bank & 57 & 2.05 & .854 & .113 \\
\hline & Oromia Cooperative Bank & 228 & 2.08 & .872 & .058 \\
\hline \multirow[t]{2}{*}{ Education } & Oromia International Bank & 57 & 3.19 & 1.187 & .157 \\
\hline & Oromia Cooperative Bank & 228 & 2.64 & 1.200 & .079 \\
\hline \multirow[t]{2}{*}{ Occupation } & Oromia International Bank & 57 & 1.00 & .000 & .000 \\
\hline & Oromia Cooperative Bank & 228 & 2.90 & 1.028 & .068 \\
\hline Monthly & Oromia International Bank & 57 & 5.00 & .000 & .000 \\
\hline Income & Oromia Cooperative Bank & 228 & 3.90 & .975 & .065 \\
\hline \multirow[t]{2}{*}{ Religion } & Oromia International Bank & 57 & 1.00 & $.000^{\mathrm{a}}$ & .000 \\
\hline & Oromia Cooperative Bank & 228 & 1.00 & $.000^{\mathrm{a}}$ & .000 \\
\hline \multirow[t]{2}{*}{ Awareness } & Oromia International Bank & 57 & 3.55 & .566 & .037 \\
\hline & Oromia Cooperative Bank & 228 & 3.79 & .364 & .048 \\
\hline \multirow[t]{2}{*}{ Compatibility } & Oromia International Bank & 57 & 3.90 & .939 & .062 \\
\hline & Oromia Cooperative Bank & 228 & 4.14 & .543 & .072 \\
\hline \multirow[t]{2}{*}{ Complexity } & Oromia International Bank & 57 & 3.53 & .811 & .054 \\
\hline & Oromia Cooperative Bank & 228 & 3.78 & .598 & .079 \\
\hline \multirow[t]{2}{*}{ Perceived Trust } & Oromia International Bank & 57 & 3.49 & .824 & .055 \\
\hline & Oromia Cooperative Bank & 228 & 3.92 & .589 & .078 \\
\hline \multirow[t]{2}{*}{ Relative Advantage } & Oromia International Bank & 57 & 3.60 & .899 & .060 \\
\hline & Oromia Cooperative Bank & 228 & 3.89 & .916 & .121 \\
\hline \multirow[t]{2}{*}{ IFB services } & Oromia International Bank & 57 & 3.63 & .724 & .048 \\
\hline & Oromia Cooperative Bank & 228 & 3.93 & .381 & .051 \\
\hline
\end{tabular}


In Table 3 below this section presents the results of selected continuous variables of the two essential normal distribution functions: Leven's test for equality of variance and the independent sample t-test for equality of means. The interpretation and analysis of the result has gone through two steps. Leven's test for equality of variance (F-test) has been first examined for each variable to check whether homogeneity of variance can be assumed followed by selection of correct t-test value.

Table 3: Independent Samples Test between Private Commercial Banks

\begin{tabular}{|c|c|c|c|c|c|c|c|c|c|c|c|}
\hline \multirow[t]{3}{*}{ Variables } & & & \multicolumn{2}{|c|}{$\begin{array}{c}\text { Levene's Test for } \\
\text { Equality of Variances }\end{array}$} & \multicolumn{7}{|c|}{ T-test for Equality of Means } \\
\hline & & & \multirow[t]{2}{*}{$\mathbf{F}$} & \multirow[t]{2}{*}{ Sig. } & \multirow[t]{2}{*}{$\mathrm{t}$} & \multirow[t]{2}{*}{ df } & \multirow[t]{2}{*}{$\begin{array}{l}\text { Sig. } \\
(2- \\
\text { tailed) }\end{array}$} & \multirow[t]{2}{*}{$\begin{array}{c}\text { Mean } \\
\text { Difference }\end{array}$} & \multirow[t]{2}{*}{$\begin{array}{l}\text { Std. Error } \\
\text { Difference }\end{array}$} & \multicolumn{2}{|c|}{$\begin{array}{l}\text { 95\% Confidence } \\
\text { Interval of the } \\
\text { Difference }\end{array}$} \\
\hline & & & & & & & & & & Lower & Upper \\
\hline \multirow[t]{2}{*}{ Gender } & $\begin{array}{l}\text { Equal } \\
\text { variances } \\
\text { assumed }\end{array}$ & & 1.034 & .310 & -3.766 & 283 & .000 & -.268 & .071 & -.407 & -.128 \\
\hline & $\begin{array}{l}\text { Equal } \\
\text { variances } \\
\text { assumed }\end{array}$ & not & & & -3.700 & 84.354 & .000 & -.268 & .072 & -.411 & -.124 \\
\hline \multirow[t]{2}{*}{ Age } & $\begin{array}{l}\text { Equal } \\
\text { variances } \\
\text { assumed }\end{array}$ & & 172 & .679 & -.205 & 283 & .838 & -.026 & .129 & -.279 & .227 \\
\hline & $\begin{array}{l}\text { Equal } \\
\text { variances } \\
\text { assumed }\end{array}$ & not & & & -.207 & 87.525 & .836 & -.026 & .127 & -.279 & .226 \\
\hline \multirow[t]{2}{*}{ Education } & $\begin{array}{l}\text { Equal } \\
\text { variances } \\
\text { assumed }\end{array}$ & & .103 & .748 & 3.142 & 283 & .002 & .557 & .177 & .208 & .906 \\
\hline & $\begin{array}{l}\text { Equal } \\
\text { variances } \\
\text { assumed }\end{array}$ & not & & & 3.162 & 86.874 & .002 & .557 & .176 & .207 & .907 \\
\hline \multirow[t]{2}{*}{ Occupation } & $\begin{array}{l}\text { Equal } \\
\text { variances } \\
\text { assumed }\end{array}$ & & 95.370 & .000 & 13.962 & 283 & .000 & -1.904 & .136 & -2.172 & -1.635 \\
\hline & $\begin{array}{l}\text { Equal } \\
\text { variances } \\
\text { assumed }\end{array}$ & not & & & 27.960 & 227.000 & .000 & -1.904 & .068 & -2.038 & -1.769 \\
\hline \multirow[t]{2}{*}{ Monthl Income } & $\begin{array}{l}\text { Equal } \\
\text { variances } \\
\text { assumed }\end{array}$ & & 90.742 & .000 & 8.478 & 283 & .000 & 1.096 & .129 & .842 & 1.351 \\
\hline & $\begin{array}{l}\text { Equal } \\
\text { variances } \\
\text { assumed }\end{array}$ & not & & & 16.978 & 227.000 & .000 & 1.096 & .065 & .969 & 1.224 \\
\hline \multirow[t]{2}{*}{ Awareness } & $\begin{array}{l}\text { Equal } \\
\text { variances } \\
\text { assumed }\end{array}$ & & 17.188 & .000 & 3.021 & 283 & .003 & .238 & .079 & .083 & .393 \\
\hline & $\begin{array}{l}\text { Equal } \\
\text { variances } \\
\text { assumed }\end{array}$ & not & & & 3.896 & 132.068 & .000 & .238 & .061 & .117 & .359 \\
\hline \multirow[t]{2}{*}{ Compatibility } & $\begin{array}{l}\text { Equal } \\
\text { variances } \\
\text { assumed }\end{array}$ & & 15.446 & .000 & 1.845 & 283 & .066 & .239 & .130 & -.016 & .494 \\
\hline & $\begin{array}{l}\text { Equal } \\
\text { variances } \\
\text { assumed }\end{array}$ & not & & & 2.514 & 150.346 & .013 & .239 & .095 & .051 & .427 \\
\hline \multirow[t]{2}{*}{ Complexity } & $\begin{array}{l}\text { Equal } \\
\text { variances } \\
\text { assumed }\end{array}$ & & 12.600 & .000 & 2.212 & 283 & .028 & .253 & .114 & .028 & .479 \\
\hline & $\begin{array}{l}\text { Equal } \\
\text { variances } \\
\text { assumed }\end{array}$ & not & & & 2.648 & 113.409 & .009 & .253 & .096 & .064 & .443 \\
\hline \multirow[t]{2}{*}{$\begin{array}{l}\text { Perceived } \\
\text { Trust }\end{array}$} & $\begin{array}{l}\text { Equal } \\
\text { variances } \\
\text { assumed }\end{array}$ & & 5.048 & .025 & 3.657 & 283 & .000 & .424 & .116 & .196 & .653 \\
\hline & $\begin{array}{l}\text { Equal } \\
\text { variances } \\
\text { assumed }\end{array}$ & not & & & 4.457 & 117.387 & .000 & .424 & .095 & .236 & .613 \\
\hline \multirow[t]{2}{*}{$\begin{array}{l}\text { Relative } \\
\text { Advantage }\end{array}$} & $\begin{array}{l}\text { Equal } \\
\text { variances } \\
\text { assumed }\end{array}$ & & .153 & .696 & 2.192 & 283 & .029 & .293 & .134 & .030 & .556 \\
\hline & $\begin{array}{l}\text { Equal } \\
\text { variances } \\
\text { assumed }\end{array}$ & not & & & 2.166 & 84.959 & .033 & .293 & .135 & .024 & .561 \\
\hline \multirow[t]{2}{*}{ IFB services } & $\begin{array}{l}\text { Equal } \\
\text { variances } \\
\text { assumed }\end{array}$ & & 22.757 & .000 & 3.047 & 283 & .003 & .302 & .099 & .107 & .498 \\
\hline & $\begin{array}{l}\text { Equal } \\
\text { variances } \\
\text { assumed }\end{array}$ & not & & & 4.342 & 168.53 & .000 & .302 & .070 & .165 & .440 \\
\hline
\end{tabular}

4.3.1.1. Awareness Factors

The results shown in above Table 4 regarding the category of Awareness Factors, the t-test for independent 
samples had a p-value of 0.000 , and that is less than the established significance level of 0.05 . Resultantly, the null hypothesis is rejected and research hypothesis is supported and it can therefore be concluded that there is a significant difference of Interest Free Banking Practices between Oromia International Bank and Oromia Cooperative Bank, $\mathrm{t}(17.188)=3.021, \mathrm{P}=0.000$ with respect to Awareness Factors. The mean score of Awareness Factors for Interest Free Banking Practices Oromia Cooperative Bank $(M=3.79 \mathrm{SD}=0.364)$ is statistically higher than that of Interest Free Banking Practices Oromia International Bank $(\mathrm{M}=3.55 ; \mathrm{SD}=0.566)$. In other words Awareness Factors Interest Free Banking Practices Oromia Cooperative Bank was significant more Awareness Factors Interest Free Banking Practices by the Awareness Factors as compared Oromia International Bank.

\subsubsection{Compatibility Factors}

The category of Compatibility Factors, the t-test for independent samples had a p-value of 0.000, and that is less than the established significance level of 0.05. Resultantly, the null hypothesis is rejected and research hypothesis is supported and it can therefore be concluded that there is a significant difference Interest Free Banking Practices between Oromia International Bank and Oromia Cooperative Bank, t $(15.446)=1.845, \mathrm{P}=$ 0.000 with respect to Compatibility Factors. The mean score of Compatibility Factors for Interest Free Banking Practices Oromia Cooperative Bank $(\mathrm{M}=4.14 \mathrm{SD}=0.543)$ is statistically higher than that of Compatibility Factors of Interest Free Banking Practices Oromia International Bank $(M=3.55 ; \mathrm{SD}=0.566)$. In other words Interest Free Banking Practices Oromia Cooperative Bank was significant more Interest Free Banking Practices by the Compatibility Factors as compared Oromia International Bank.

\subsubsection{Complexity Factors}

The results shown in above Table 4 regarding the category of Complexity Factors, the t-test for independent samples had a p-value of 0.000 , and that is less than the established significance level of 0.05 . Resultantly, the null hypothesis is rejected and research hypothesis is supported and it can therefore be concluded that there is a significant difference Interest Free Banking Practices between Oromia International Bank and Oromia Cooperative Bank, $\mathrm{t}(12.600)=2.212, \mathrm{P}=0.000$ with respect to Complexity Factors. The mean score of Complexity Factors for Interest Free Banking Practices Oromia Cooperative Bank $(\mathrm{M}=3.78, \mathrm{SD}=0.598)$ is statistically higher than that of Interest Free Banking Practices Oromia International Bank $(\mathrm{M}=3.53 ; \mathrm{SD}=0.811)$. In other words Interest Free Banking Practices Oromia Cooperative Bank was significant more Interest Free Banking Practices by the Complexity Factors as compared Oromia International Bank.

\subsubsection{Perceived Trust Factors}

Regarding the category of Perceived Trust Factors, the t-test for independent samples had a p-value of 0.025 , and that is less than the established significance level of 0.05 . Resultantly, the null hypothesis is rejected and research hypothesis is supported and it can therefore be concluded that there is a significant difference Interest Free Banking Practices between Oromia International Bank and Oromia Cooperative Bank, t $(5.048)=3.657, \mathrm{P}$ $=0.000$ with respect to Perceived Trust Factors. The mean score of Perceived Trust Factors for Interest Free Banking Practices Oromia Cooperative Bank $(M=3.92, S D=0.589)$ is statistically higher than that of Interest Free Banking Practices Oromia International Bank $(\mathrm{M}=3.49$; $\mathrm{SD}=0.824)$. In other words Interest Free Banking Practices Oromia Cooperative Bank was significant more Interest Free Banking Practices by the Perceived Trust Factors as compared Oromia International Bank.

\subsubsection{Relative Advantage Factors}

The results shown Relative Advantage Factors, the t-test for independent samples had a p-value of 0.696, and that is higher than the established significance level of 0.05 . Resultantly, the null hypothesis is accepted and research hypothesis is not supported and it can therefore be concluded that there is a no significant difference Interest Free Banking Practices between Oromia International Bank and Oromia Cooperative Bank, t $(0.153)=$ 2.192, $\mathrm{P}>0.05$ with respect to Relative Advantage Factors. The mean score of Relative Advantage Factors for Interest Free Banking Practices Oromia Cooperative Bank $(\mathrm{M}=3.89, \mathrm{SD}=0.916)$ is statistically higher than that of Interest Free Banking Practices Oromia International Bank $(\mathrm{M}=3.60 ; \mathrm{SD}=0.899)$. In other words Interest Free Banking Practices Oromia Cooperative Bank was significant more Interest Free Banking Practices by the Relative Advantage Factors as compared Oromia International Bank.

\subsubsection{Implementation of Interest Free Banking Practices in Private Commercial Banks}

The Implementation of Interest Free Banking Practices in Private Commercial Banks, the t-test for independent samples had a p-value of 0.000 , and that is less than the established significance level of 0.05 . Resultantly, the null hypothesis is rejected and research hypothesis is supported and it can therefore be concluded that there is a significant difference Overall Implementation of IFBP between Oromia International Bank and Oromia Cooperative Bank, $t(22.757)=3.047, \mathrm{P}=0.000$ with respect to Awareness Factors. The mean score of Overall Implementation of Interest Free Banking Practices Oromia Cooperative Bank $(\mathrm{M}=3.93 \mathrm{SD}=0.381)$ is statistically higher than that of Interest Free Banking Practices Oromia International Bank $(M=3.55 ; \mathrm{SD}=0.566)$. In other words Overall Implementation of Interest Free Banking Practices Oromia Cooperative Bank was significant more Interest Free Banking Practices by the Overall Implementation of IFBP as compared Oromia International 
Bank.

\subsection{Ordinal logistic (O logit) regression model}

Ordinal logistic (O logit) regression to see the effects of independent variables on dependent variable by using Statistical Packages for Social Sciences (SPSS) version 26 software. Ordinal logistic (O logit) regression model parameters using the maximum likelihood estimator, there is a need to assess the significance of the variables with regards to predicting the response variable. There are a number of statistics that can be used to carry out the assessment and these include deviance, likelihood ratio, Wald Test and Score Test (Harrell, 2001). These tests are discussed in the sections below.

\subsubsection{Model fitting information}

The model fitting information shown in table 5 below had significant value of 0.000 which describe the model was fit for logistic regression information. Ordinal logistic (O logit) regression is used in the analysis because it was the predictor variables that are statistically significant in the model.

Table 5: Model fitting information

\begin{tabular}{lrrrr}
\hline Model & $\mathbf{- 2}$ Log Likelihood & Chi-Square & df & Sig. \\
\hline Intercept Only & 859.789 & & & \\
Final & 788.298 & 71.491 & 10 & .000 \\
\hline
\end{tabular}

Link function: Logit

According to Prempeh, (2009) the likelihood-ratio test is chi-square distributed and if test is significant then the dropped variable was a significant predictor in the equation whilst on the other hand if the test is not significant then the variable is considered to be unimportant and thus is excluded from the model.

\subsubsection{Goodness-of-Fit}

The observed values of the dependent variable must be compared with the estimated values obtained from models with and without the variable in question. This comparison is based on the log-likelihood function according to Hosmer and Lemeshow (2000), the statistic D, is called the deviance, and it plays an essential role in the assessment of goodness of fit of the model. The deviance plays the same role in logistic regression as the residual sum of squares plays in linear regression. A p-value greater than 0.05 (the significance level) is an indication that at least one coefficient is non-zero (Abdelrahman, 2010). The goodness of fit of fit table contains the Pearson and Deviance chi-square tests, which are useful for determining whether a model exhibits good fit to the data. Non-significant tests results are indicators that the model fits the data well (Field \& Miles, 2010). In this analysis, both the Pearson chi-square test $\left[x^{2}(1126)=1197.938, \mathrm{P}=0.067\right]$ and the deviance test $\left[x^{2}(1126)\right.$ $=788.298, \mathrm{P}=1.000]$ were non-significant these results suggest good model fit.

\section{Table 6: Goodness-of-Fit}

\begin{tabular}{lccc}
\hline & Chi-Square & df & Sig. \\
\hline Pearson & 1197.938 & 1126 & .067 \\
Deviance & 788.298 & 1126 & 1.000 \\
\hline \multicolumn{4}{c}{ Link function: Logit. }
\end{tabular}

\subsubsection{Pseudo R-Square}

The fourth test of fitness was Pseudo R-Squire which showed how the model explained by the Explanatory variable using those three variables describes the model ability of determination in contrary to the common use of $\mathrm{R}^{2}$. These indicators that substitute the classical coefficient of determination of $\mathrm{R}^{2}$ is called pseudocoefficients of determination and are for ordinal regression the statistics of Cox and Snell (Cox and Snell, 1989), of Negelkerke (Nagelkerke,1991) and of McFadden,(McFadden, 1974) the Result of this pseudo-coefficients are also presented at table 7 .

The value of Cox and Snell's (0.622) and Negelkerke's (0.633) statistics indicate an obvious good fitting ability for the model the corresponding value of McFadden (0.083) can be considered acceptable. As a result, almost 63.3\% (Negelkerke's $=0.633$ ) of interest free banking practices between Private Commercial Banks in Dire Dawa Districts by those statistically significant antecedents in this study. The Nagelkereke $\mathrm{R}^{2}$ indicates the model can for $63.3 \%$ of the variance in the implementation of interest free banking practices.

Table 7: Pseudo R-Square

\begin{tabular}{ll}
\hline Cox and Snell & .622 \\
Negelkerke & .633 \\
McFadden & .083 \\
\hline
\end{tabular}

\subsubsection{Test of Parallel Lines}

Link function: Logit.

The last procedure for the evaluation of the model is the parallel line tests (see table 8) this test of the model, because it helps to assess, whether the assumption that the parameters are the same for all categories is 
reasonable. Substantially parallel lines test suggest a hypothesis testing the null hypothesis was acceptable (Norusis, 2004) when $P$ value presents higher score than 0.05 or 0.1 (McCullagh \& Nelder, 1980). In the case of ordinal model the null hypothesis was not accepted since the statistical significance was $\mathrm{P}$ value less than 0.05 .

Table 8: Test of Parallel Lines

\begin{tabular}{lcccc}
\hline Model & $\mathbf{- 2}$ Log Likelihood & Chi-Square & df & Sig. \\
\hline Null Hypothesis & 788.298 & & & \\
General & $653.445^{\mathrm{b}}$ & $134.853^{\mathrm{c}}$ & 30 & .000 \\
\hline
\end{tabular}

This is the log likelihood of the fitted model. It is used in the Likelihood Ratio Chi-Square test of whether all predictors' regression coefficients in the model are simultaneously zero.

\subsubsection{Logistic Regression Parameter Estimates}

Regressions of the data was computed using order logit link and predict the factors of interest free banking practices with implementation of interest free banking in private commercial banks antecedents and the following regression output of the model were summarized in table 9.

Table 9: Logistic Regression Parameter Estimates

\begin{tabular}{|c|c|c|c|c|c|c|c|c|}
\hline \multirow[b]{2}{*}{ Variables } & & \multirow[b]{2}{*}{ Estimate } & \multirow[b]{2}{*}{$\begin{array}{l}\text { Std. } \\
\text { Error }\end{array}$} & \multirow[b]{2}{*}{ Wald } & \multirow[b]{2}{*}{$\mathrm{df}$} & \multirow[b]{2}{*}{ Sig. } & \multicolumn{2}{|c|}{$95 \% \mathrm{CI}$} \\
\hline & & & & & & & $\begin{array}{l}\text { Lower } \\
\text { Bound }\end{array}$ & $\begin{array}{l}\text { Upper } \\
\text { Bound }\end{array}$ \\
\hline \multirow[t]{4}{*}{ Threshold } & {$[\mathrm{IFB}=1]$} & 3.531 & 1.536 & 5.285 & 1 & .022 & .520 & 6.542 \\
\hline & {$[\mathrm{IFB}=2]$} & 5.446 & 1.539 & 12.514 & 1 & .000 & 2.428 & 8.463 \\
\hline & {$[\mathrm{IFB}=3]$} & 6.633 & 1.556 & 18.168 & 1 & .000 & 3.583 & 9.683 \\
\hline & {$[\mathrm{IFB}=4]$} & 7.908 & 1.575 & 25.211 & 1 & .000 & 4.821 & 10.995 \\
\hline \multirow[t]{11}{*}{ Location } & Sex & -.600 & .228 & 6.905 & 1 & .000 & -1.047 & -.152 \\
\hline & Age & .085 & .133 & .411 & 1 & .521 & -.176 & .347 \\
\hline & Education & .017 & .097 & .030 & 1 & .864 & -.174 & .207 \\
\hline & Occupation & .215 & .208 & 1.067 & 1 & .302 & -.193 & .622 \\
\hline & Awareness & 3.876 & .701 & 30.533 & 1 & .000 & 2.501 & 5.251 \\
\hline & Compatibility & -.942 & .234 & 16.193 & 1 & .000 & -1.400 & -.483 \\
\hline & Complexity & -.452 & .240 & 3.528 & 1 & .060 & -.923 & .020 \\
\hline & Perceived Trust & -.550 & .228 & 5.837 & 1 & .016 & -.996 & -.104 \\
\hline & Relative Advantage & 7.908 & 1.575 & 25.211 & 1 & .000 & 4.821 & 10.995 \\
\hline & Income & 5.446 & 1.539 & 12.514 & 1 & .000 & 2.428 & 8.463 \\
\hline & {$[$ Religion $=1]$} & $0^{\mathrm{a}}$ & & & 0 & & & \\
\hline
\end{tabular}

Link function: Logit.

a. This parameter is set to zero because it is redundant.

\subsection{Result and Discussion}

The regression results are shown in Table 9 above the ordered logit regression model was also fitted to estimate the effects of a unit change in the individual hypothesized explanatory variable of interest free banking practices towards implementation of interest free banking service in private commercial banks.

\subsubsection{Awareness Factors}

From the coefficient for "Awareness" is 3.876, has positive and significant influence [beta $(\beta)=3.876$; Wald Statistics $=30.533 ; \mathrm{P}=0.000]$ on implementation of interest free banking practices (service) in private commercial banks. For one-unit increase in "Awareness", there will be 3.876 (the odds ratio= $\mathbf{e}^{\text {estimates }=} \mathbf{e}^{\mathbf{3 . 8 7 6} \text { ) }}$ increase 48.2 times significantly implementation of interest free banking practices (service) in private commercial banks increases in the probability of log-odds of being higher level of IFB practices (service); in other words ceteris paribus (other predictors remains constant), will lead to the private commercial banks to be increases by 48.2 times likely to implement of interest free banking. Thus, a high value of "Awareness" is associated with an increase in implementation of interest free banking practices (service) in private commercial banks.

Hypothesis 1: Awareness has a significant and positive influence on interest free banking practices in private commercial banks.

Hence, hypothesis 1 is supported. The results showed that awareness of Islamic banking services has significance effect on the implementation of interest free banking service in private commercial banks. Thus from this finding is in accordance with the findings of the studies by (Rammal and Zurbrugg, 2007; Thambiah et al., $2011 \mathrm{a}$; Echchabi and Aziz, 2012b) which indicated customer's awareness have a significant relation with the implementation of Islamic Banking.

\subsubsection{Compatibility Factors}

From table 9, the coefficient for "Compatibility" is -0.942 , has negative and significant influence [beta $(\beta)=$ 0.942; Wald Statistics $=16.193 ; \mathrm{P}=0.000]$ on implementation of interest free banking practices (service) in 
private commercial banks. For one-unit increase in "Compatibility" there will be -0.942 (the odds ratio= $\mathbf{e}^{\text {estimates }}=\mathbf{e}^{\mathbf{- 0 . 9 4 2}}$ ) increase or decreases 0.389 times significantly implementation of interest free banking practices (service) in private commercial banks increases or decreases in the probability of log-odds of being lower level of IFB practices (service); in other words ceteris paribus (other predictors remains constant), will lead to the private commercial banks to be increase or decreases by 0.389 more times likely to implementation of interest free banking. Thus, a low value of "Compatibility" is associated with an increase or decreases in implementation of interest free banking practices (service) in private commercial banks.

Hypothesis 2: Compatibility has a significant and negative influence on interest free banking practices in private commercial banks.

Hence, Hypothesis 2 is supported. This is in line with the findings of (Echchabi and Aziz, 2012a; Tan and Teo, 2000; Nor, 2005 and Thambiah et al., 2011a). Another study by Raman (2010) indicates that construct compatibility appear to be insignificant in influencing the decision to adopt or not the Islamic banking products. Compatibility turns out to be the most important factor in the Islamic banking adoption products and services observe Islamic banking as well suited to their existing habits, needs and style.

\subsubsection{Complexity Factors}

From the coefficient for "Complexity" is -0.452 , has negative and insignificant influence [beta $(\beta)=-0.542$; Wald Statistics $=3.528 ; \mathrm{P}=0.06]$ on implementation of interest free banking practices (service) in private commercial banks. For one-unit increase in "Complexity", there will be -0.255 (the odds ratio= $\mathbf{e}^{\text {estimates }=} \mathbf{e}^{-\mathbf{0 . 4 5 2}}$ ) decrease 0.636 times significantly implementation of interest free banking practices (service) in private commercial banks decreases in the probability of log-odds of being higher level of IFB practices (service); in other words ceteris paribus (other predictors remains constant), will lead to the private commercial banks to be decreases by 0.636 times likely to implementation of interest free banking. Thus, a low value of "Complexity" is associated with a decrease in implementation of interest free banking practices (service) in private commercial banks.

Hypothesis 3: Complexity has negative and insignificant influence on interest free banking practices in private commercial banks.

Hence, Hypothesis 3 is not supported. Although perceived complexity negatively affects the attitude of customers towards implementation of Interest free banking, it is statistically insignificant $p$ value $0.60 \%$ of greater than $(0.05)$ at significance level as shown in the above table that support the null hypothesis which says, there is a negative relationship between complexity and implementation of Interest free banking window services. Complexity has negative and insignificant not influence the attitude of customers towards interest frees banking. This is similar to the findings of the study with, Shih and Fang, (2004), as well as Taylor and Todd, (1995). Therefore, even though Islamic banking services can be considered as a new concept, it is still a form of continuous financial innovation, which suggests that customers are not required to create many changes in their usage pattern of banking services. The findings of this study reveal that 'Complexity' is negatively associated with the Islamic banking adoption. This illustrates that individuals are not likely to adopt Islamic banking if they discover that such products and services are complicated and difficult to understand.

\subsubsection{Perceived trust Factors}

The coefficient for "Perceived trust" is -0.550 , has negative and significant influence $[$ beta $(\beta)=-0.550$; Wald Statistics $=5.837 ; \mathrm{P}=0.01]$ on implementation of interest free banking practices (service) in private commercial banks. For one-unit increase in "Perceived trust", there will be -0.255 (the odds ratio $=\mathbf{e}^{\text {estimates }}=\mathbf{e}^{\mathbf{- 0 . 5 5 0}}$ ) increase or decreases 0.576 times significantly implementation of interest free banking practices (service) in private commercial banks increases or decreases in the probability of log-odds of being lower level of IFB practices (service); in other words ceteris paribus (other predictors remains constant), will lead to the private commercial banks to be increase or decreases by 0.576 more times likely to implementation of interest free banking. Thus, a low value of "Perceived trust" is associated with an increase or decreases in implementation of interest free banking practices (service) in private commercial banks.

Hypothesis 4: Perceived trust has a significant and negative influence on interest free banking practices in private commercial banks.

Perceived trust has negative and significant influence the attitude of customers towards interest frees banking. As a result, the alternate hypothesis (H4) is accepted, while the respective null hypothesis rejected. This finding supports (Doraisamy, Shanmugam and Raman, 2011; Ostlund, 1974; Zhao et al., 2010). Thus, much emphasis on the marketing and management strategies should be on the shariah complaint, religious value, and the specific financial needs and secured investment in line with the philosophy of doing banking businesses. It is worth mentioning that the main dimensions measuring 'Perceived Trust' in this study is the perception of customers on the security and trustworthiness of Islamic institutions, how the banks deal with clients and compliance with the Shariah principles.

\subsubsection{Relative Advantage Factors}

From table 9, the coefficient for "Relative Advantage", is 7.908, has positive and significant influence [beta $(\beta)$ 
$=7.908 ;$ Wald Statistics $=25.211 ; \mathrm{P}=0.000]$ on implementation of interest free banking practices (service) in private commercial banks. For one-unit increase in "Relative Advantage", there will be 7.908 (the odds ratio= $\mathbf{e}^{\text {estimates }}=\mathbf{e}^{\mathbf{7 . 9 0 8}}$ ) increases 2.718 times significantly implementation of interest free banking practices (service) in private commercial banks increase in the probability of log-odds of being lower level of IFB practices (service); in other words ceteris paribus (other predictors remains constant), will lead to increase the private commercial banks by 2.718 more times likely to implementation of interest free banking. Thus, a low value of "Relative Advantage" is associated with increase in implementation of interest free banking practices (service) in private commercial banks.

Hypothesis 5: Relative advantage has a significant and positive influence on interest free banking practices in private commercial banks. Thus alternative hypothesis (H5) is accepted whereas the respective null hypothesis is rejected. This finding supports Nain Tara (2014) and Echchabi et al., (2014) the perceived relative advantage emerged as the best predictor of customers' acceptance of Islamic banking services. They indicated that relative advantage have a significant effect on the customers' intention to adopt Islamic Banking service.

\subsubsection{Demographic factor}

Hypothesis 6: Demographic factor such as (sex and monthly income) has a significant and positive influence on interest free banking practices in private commercial banks. Sex and monthly income with a $p$ value of less than 0.05. Thus, the alternate hypotheses for these constructs are accepted and null hypotheses rejected. The coefficient for Demographic factors such as Age, educational status and occupation has negative and insignificant influence on interest free banking practices in private commercial banks with a $\mathrm{p}$ value of greater than 0.05. Thus, the null hypotheses for these constructs are accepted and alternate hypotheses rejected. The present findings clearly imply that religious beliefs reasons are still instrumental in influencing the implementation of IFB products and services to certain extend. Therefore, religious beliefs reason could be the contributing factor for the interest free banking customers in particular to perceive IFB products and services as fair and economically advantages, a banking system instilled with religious principles. This result is consistent with the findings of (Thambiah et al., 2013; and Abdul Ghafoor Awan \& Maliha, 2014).

\section{Conclusion and Recommendations}

On the basis of the findings the following conclusions and recommendations are forwarded in order to improve the interest free banking practices in private commercial banks of Oromia International Bank and Oromia Cooperative Bank in Dire Dawa.

* The number of customers and deposits also increased when banks start to provide Interest free banking products. The survey also revealed that interest free banking service benefits banks to improve competitiveness and enhance bank's brand image by serving as an alternative banking system. Interest free banking services have been benefiting, not only in terms of increasing customers and mobilizing deposits, but also some banks enjoy greater profitability generation. This indicates private commercial banks currently having Interest free banking window have been benefited from the operation of Interest free banking services.

\# The basic awareness of the customers and their essential knowledge about Interest free banking and Shariah based products and services in the market have positively influenced their perception and usage towards the Interest free banking. However, majority of the account holders did not well understand the basic principle used in interest free banking. Furthermore, it is unlikely to aware every type of interest free banking products and services, but the majority of account holders little aware or unaware for most of interest free products.

* Awareness and Relative advantage the significant factor on interest free banking practices in private commercial banks Islamic banking products and services. These two factors explain the degree to which the benefits of using Islamic banking products and services can be observed and communicated with the other members in the social system. The benefits here can be described in the dimensions of economic profitability, social prestige, low initial cost, the immediacy of the reward, a decline in discomfort, and a saving in effort and time which have been depicted as sub-divisions of relative advantage.

* In terms of public awareness of IFB products, we recommend the first step would be to inform the client base which has opted out of receiving interest on the conventional products, their new accounts terms and conditions. A clear explanation that their monies will now be used to finance projects which are in compliance with Islamic financial principles should be provided to these customers.

* Obtaining feedback from existing and prospective IFB customers could be used as a base for developing an adequate marketing strategy for IFB products. Further marketing and communications strategies can be developed as regulations and products are put in place.

* The survey also revealed that interest free banking service it shows that "Complexity" have statistically insignificant and negative relationship with the implementation of interest free banking service. Thus, banks need to take these factors into account when developing their Shariah compliant products and 
services to ensure the success of their Islamic banking products and services. Banks need to enhance accessibility, profitability and service quality factors.

* The Bank need to consider on the intense regular training programs, Seminars, workshops on Islamic finance, and standards and procedures of Interest free banking must be organized for the officials and employees on the interest free counters of the by private commercial banks as a result they can aware customers through their daily activities on issues raised from the customer regarding the implementation of interest free banking service.

\section{Suggestions for Further Research}

The main objective of this study was to assess interest free banking practices in Ethiopia private commercial banks in Dire Dawa. This study was conducted in Oromia International Bank and Oromia Cooperative Bank in Dire Dawa and may not be generalizing to other Private Commercial Banks and Public owned Commercial Bank of Ethiopia in Dire Dawa. The study was to emphasize Awareness, Compatibility, Complexity, Perceived trust; Relative Advantage and Demographic factors (sex, age, educational status, and occupation, religion and monthly income) with implementation of interest free banking practices in private commercial banks are not the only factors that contribute to interest free banking practices. Further studies shall also be carried out to investigate other factors that might be affecting interest free banking system in public and commercial banks and in the future studies may replicate this study to other Private Commercial Banks or Public Commercial Banks.

\section{REFERENCES}

Abdelrahman A.I., (2010) Applying Logistic Regression Model to the Second Primary Cancer Data. Ain Shams University Egypt.

Abdul Ghafoor, Awan \& Maliha Azhar. (2014) Consumer behavior towards Islamic banking in Pakistan, European Journal of Accounting, Auditing and Finance Research

Abraham .R. (2017) Determinants of Customers' Intention to Use Interest Free Banking Products and Factors Affecting Employees' Product Knowledge: The case of Commercial Bank of Ethiopia. Master Thesis (MBA), Addis Ababa University.

Agarwal, R., and Prasad, J. (2009) A conceptual and operational definition of personal innovativeness in the domain of information technology Information systems research, 9(2), 204-215

Ahmad, N. and Haron S. (2002) Perceptions of Malaysian corporate customers towards Islamic banking products and services International Journal of Islamic Financial Services, Vol. 3 No. 4, pp. 13-29

Akmel, H. (2015) Challenges and Prospects of Islamic Banking for Resource Mobilization in Ethiopian Commercial Banks an unpublished MBA thesis St. Mary’s University, Department Of Accounting And Finance

Alharbi, A. (2015). Development of the Islamic Banking System Journal of Islamic Banking and Finance, 3(1), $12-25$.

Anuar, M. M., Adam, F. and Mohamad, Z. (2012b) Muslim Consumerse Perception on Internet Banking Services International Journal of Business and Social Science, 3, 63-71

Arts, J. W. C., Frambach, R. T., \& Bijmolt, T. H. A. (2011) Generalizations on consumer innovation adoption: A meta-analysis on drivers of intention and behavior. International Journal of Research in Marketing, 28(2), $134-144$

Bahri S, Hamzah D, Yus RM. (2012) Implementation of Total Quality Management and Its Effect on Organizational Performance of Manufacturing Industries through Organizational Culture in South Sulawesi, Indonesia. IOSR Journal of Business and Management; 5(1):10-24.

Beiglo, S. H. B. and Zare, R. (2011) A Survey on Factors Effecting Continuity the Use of Government" EServices. Australian Journal of Basic and Applied Sciences, 5, 209-220.

Bley, J. and Kuehn, K. (2004), "Conventional versus Islamic finance: student knowledge and perception in the United Arab Emirates”, International Journal of Islamic Financial Services, Vol. 5 No. 4, pp. 17-30.

Brown, I., Cajee, Z., Davies, D. \& Stroebel, S. (2003) Cell phone banking: predictors of adoption in South Africa an exploratory study. International Journal of Information Management, 23, 381-394

Cerf V.G (2010), Trust and the Internet, IEEE Internet Computing, Backspace, pp 95-96

Cochran, W.G. (1963) Sampling Techniques, Wiley, New York

Corrigan, J. A. (2012). The implementation of e-tutoring in secondary schools: A diffusion study. Computers \& Education

Cox, D. R., and E. J. Snell (1989) The Analysis of Binary Data, 2nd ed. London: Chapman and Hall

Daud, M., Yussof, I. M. and Abideen, A. (2011), the establishment and operation of Islamic Banks in Nigeria: Perception study on the role of the Central Bank of Nigeria. Australian Journal of Business and Management Research Vol, 1

Debebe Alemu (2015). Factors Affecting Customers' to Use Interest Free Banking in Ethiopia unpublished 
project paper Addis Ababa University Ethiopia

Directives of National Bank of Ethiopia SBB/51/2011

Doraisamy, B., Shanmugam, A. and Raman, R. (2011) A study on consumers' preferences of Islamic banking products and services in Sungai Petain Academic Research International, 1(3): 201-210.

Echchabi, A., \& Aziz, H. A. (2012a), The relationship between religiosity and customers' adoption of Islamic banking services in Morocco. International Journal of Contemporary Business Studies, 3(5), 25-31

Echchabi, A., \& Aziz, H.A. (2012b). The relationship between religiosity and customers' adoption of Islamic banking services in Morocco. Arabian Journal of Business and Management review (OMAN Chapter), 1(10), 89-94.

Elahi, S., \& Hassanzadeh, A. (2009) A framework for evaluating electronic commerce adoption in Iranian companies International Journal of Information Management, 29(1), 27-36.

Firtle, G.N. (2013) Marketing Research: An Applied Orientation, 4th ed Pearson Prentice Hall, Upper Saddle River, N.J.

Flight, R. L., D'Souza, G., \& Allaway, A. W. (2011) Characteristics-based innovation adoption: scale and model validation. Journal of Product \& Brand Management, 20(5), 343-355.

Franzoni, S., \& Ait Allali, A. (2018) Principles of Islamic Finance and Principles of Corporate Social Responsibility What Convergence Sustainability, 10(3), 637

Gefen, D. 2000. E-commerce: the role of familiarity and trust. Omega, 28, 725-737

George, J. F. (2002) Influences on the intent to make Internet purchases Internet Research, 12, 165-180.

Gerrard, P. and Cunningham, J.B. (2003b), "The diffusion of internet banking among Singapore consumers", International Journal of Bank Marketing, Vol. 21 No. 1, pp. 16-28.

Gholami, R., Ogun, A., Koh, E. and Lim, J. (2010) Factors affecting e-payment adoption in Nigeria. Journal of Electronic Commerce in Organizations (JECO), 8, 51-67.

Giovanis, A. N., Binioris, S., \& Polychronopoulos, G. (2012), An extension of TAM model with IDT and security/privacy risk in the adoption of internet banking services in Greece. Euro Med Journal of Business, 7(1), 24-53.

Gujarati, D.N., (2004) Basic econometric, 4th International ed. McGraw Hill New York, USA

Hamid, A and Nordin N (2001) A study on Islamic banking education and strategy for the new millennium Malaysian experience International Journal of Islamic Financial Services 2(4)

Haron, S., Ahmad, N., and Planisek, S. L. (1994) Bank patronage factors of Muslim and non-Muslim customers International Journal of Bank Marketing, 12(1), 32-40

Harrell F. E, Jr., (2001) Regression Modeling Strategies: With Applications to Linear Models, Logistic Regression, and Survival Analysis. Springer

Hernandez, J. M. C., \& Mazzon, J. A. (2007) Adoption of internet banking: proposition and implementation of an integrated methodology approach. International Journal of Bank Marketing, 25(2), 72-88.

Hosmer D. W., and Lemeshow S., (2000) Applied Logistic Regression, Second Edition. John Wiley \& Sons

Hsu, C. L., Lu, H. P. and Hsu, H. H. (2007) Adoption of the mobile Internet: An empirical study of multimedia message service (MMS). Omega, 35, 715-726.

Kerima, A. (2016), Challenges on Interest Free Banking Services: The Case of Commercial Bank of Ethiopia, An EMBA Thesis submitted to Addis Ababa University, Department of management

Khattak, N.A. and Rahman, K. U. R. (2010), "Customer satisfaction and awareness of Islamic banking system in Pakistan”, African Journal of Business Management, Vol. 4 No. 5, pp. 662-671

Kim, H., Kim, T. T. and Shin, S. W. (2009) Modeling roles of subjective norms and e Trust in customers' acceptance of airline B2C e Commerce websites. Tourism Management, 30, 266-277.

Lee, Y. H., Hsieh, Y. C. and Hsu, C. N. (2011) Adding Innovation Diffusion Theory to the Technology Acceptance Model: Supporting Employeese ${ }^{e}$ Intentions to use E-Learning Systems. Educational Technology \& Society, 14,124-137

Liu, T. C. and Wu, L. W. (2007) Customer retention and cross-buying in the banking industry: an integration of service attributes satisfaction and trust. Journal of Financial Services Marketing, 12, 132-145.

Mayer, R. C., Davis, J. H. and Schoorman, F. D. (1995) An integrative model of organizational trust. Academy of management review, 709-734

McFadden, D. Conditional logit analysis of qualitative choice behavior (1974) In: Frontiers in Economics, P.

Zarembka, eds New York: Academic Press

Metawa, S.and M. Almossawi, (1998) Banking behavior of Islamic bank's customers: Perspectives and Implications. International journal of bank marketing, 16(7): 299-315

Mohammad T., Mohd Y., Mohd A and Ummu Z (2013), the historical development of modern Islamic banking: A study in South-east Asia countries. African journal of business management

Mohammed, M. (2012) Islamic banking: Prospects, opportunities and challenges in Ethiopia, An MBA Thesis submitted to Addis Ababa University, Department of Accounting and Finance 
Munizu M. (2013) The Impact of Total Quality Management Practices towards Competitive Advantage and Organizational Performance: Case of Fishery Industry in South Sulawesi Province of Indonesia Pakistan Journal of Commerce and Social Sciences. Vol. 7(1), 184-197

Nagelkerke, N. J. D. (1991) A note on the general definition of the coefficient of determination. Biometrika, vol. 78, pp. 691-692.

Naser, K., Jamal, A. and Al-Khatib, K. (1999), "Islamic banking: a study of customer satisfaction and preferences in Jordan", The Internal Journal of Bank Marketing, Vol. 17 No. 3, pp. 135-51.

Ndubisi, N. O. and Sinti, Q. (2006) Consumer attitudes, system's characteristics and internet banking adoption in Malaysia Management Research News, 29, 16-27.

Nobel Demissie (2019) "Factors Affecting Implementation of Interest Free Banking Services in Ethiopia: The Mediation Role of Customer Involvement" unpublished thesis Masters of Business Administration Addis Ababa University

Nor, K., Pearson, J. M. \& Ahmad, A. (2010) Adoption of internet banking: Theory of the diffusion of innovation International Journal of Management Studies, 17, 69-85

Okumus, S.H., (2005) Interest free banking in Turkey: a study of customer satisfaction and bank selection criteria. Journal of Economic Cooperation, 26(4): 51-86.

Oromia International Bank (2018) Interest Free Banking. https://www.orointbank.com/node/88

Ostlund, Lyman E. (1974), Perceived Innovation Attributes as Predictors of Innovativeness. Journal of Consumer Research, 1, 23-29.

Papies, D., \& Clement, M. (2008) Adoption of new movie distribution services on the Internet. Journal of Media Economics, 21(3), 131-157.

Prempeh E. A., (2009. Comparative Study of the Logistic Regression Analysis and the Discriminant Analysis University of Cape Coast

Rammal H.G. \& Zurbruegg R. (2007) Awareness of Islamic Banking Products among Muslims: The Case of Australia. Journal of Financial Services Marketing, 12(1), 65-74.

Rogers, E. M. (2003). Diffusion of innovations (5thedition) The Free Press: New York

Rogers, E., (1983) Diffusion of Innovations. The Free Press, New York.

Rogers, E.M. (1995) Diffusion of innovations Fourth edition New York Free Press

Saini, Y., Bick, G., and Abdulla, L. (2011) Consumer awareness and usage of Islamic banking products in South Africa South African Journal of Economic and Management Sciences, 14(3), 298-313

Shih, Y. and Fang, K. (2004) The use of decomposed theory of planned behavior to study Internet banking in Taiwan, Internet Research, 14(3), 213-223

Sipior, J.C., Bard, B.T. \& Rongione, N.M. (2004) Ethics of collecting and using consumer internet data. Information System Management, 21, 1, 58-66.

Sohail, S. and Shanmugham, B. (2003) E-banking and customer preferences in Malaysia: An empirical investigation Information Sciences, 150, 207-217

Suadiq Mehammed Hailu and Ibrahim Bushera (2020) Interest Free Banking in Ethiopia: Prospects and Challenges International Journal of Islamic Economics and Finance Studies, 2020/2: 119-137 DOI: 10.25272/ijisef.678972

Sugiyono J. (2008) Statistics for Research Bandung, Indonesia Alfabeta Press

Suh, B., \& Han, I. (2003) Effect of trust on customer acceptance of Internet banking. Electronic Commerce Research and Applications, 1(3-4), 247-263

Tan, M., \& Teo, T. (2000) Factors influencing the adoption of Internet banking. Journal of the Association for Information Sciences, 1, 1-42.

Taylor, S. and Todd, P. A. (1995) Understanding information technology usage: A test of competing models Information systems research, 6(2):144-176.

Teferi, M (2015). Contribution of IFB to economic development and its prospect in Ethiopia, An EMBA Thesis submitted to Addis Ababa University, Department of Management.

Thambiah, S., Eze, U. C., Santhapparaj, A. J., \& Arumugam, K. (2011a) Customers' Perception on Islamic Retail Banking: A Comparative Analysis between the Urban and Rural Regions of Malaysia International Journal of Business \& Management, 6(1)

Thambiah, S., Ismail, H., Ahmed, E. M., \& Khim, A. A. (2013) Islamic Retail Banking Adoption in Malaysia:The Moderating of Religion and Region International Journal of Applied Economics \& Finance, 7(1).

Thambiah, S., Ramanathan, S. \& Mazumder, M.N.H. (2012) The determinants of Islamic retail banking adoption in Malaysia, International Business \& Economics Research Journal (IBER),11(4), 437-442.

Thambiah, S.; Eze, U. C.; Santhapparaj, A. J. \& Arumugam, K. (2011b) Customerse Perception on Islamic Retail Banking: A Comparative Analysis between the Urban and Rural Regions of Malaysia. International Journal of Business and Management, 6 (1), 187- 198 
Tornatzky, L. G., \& Klein, K. J. (1982) Innovation characteristics and innovation adoption-implementation: A meta-analysis of findings. IEEE Transactions on engineering management, 29(1), 28-45.

Tsion sisay (2017), Challenges and opportunities of interest free banking in Ethiopia .A Thesis submitted to the Department of Accounting and Finance for the fulfillment of the requirements of the Degree of Master of Science in Accounting and Finance

Tung, F. C., Chang, S. C. and Chou, C. M. (2008), An extension of trust and TAM model with IDT in the adoption of the electronic logistics information system in HIS in the medical industry. International journal of medical informatics, 77, 324

Wang, M. S., Chen, C. C., Chang, S. C., and Yang, Y. H. (2007) The selection of banks and banking services among corporate customers in South Africa, International Journal of Bank Marketing, Vol. 7 No. 5, pp. $36-43$.

Wang, M. S., Chen, C. C., Chang, S. C., and Yang, Y. H. (2010) Effect of Online Shopping Attitudes, Subjective Norms and Control Beliefs on Online Shopping Intentions: A Test of the Theory of Planned Behavior. International Journal of Management, 24(2), 296-302.

Wondwosen Teshome (2018) operational challenges and opportunities of interest free banking in Ethiopia unpublished thesis submitted to Addis Ababa University College of business and economics department Addis Ababa Ethiopia

Wu, J. H., Wang, S. C., \& Lin, L. M. (2007) Mobile computing acceptance factors in the healthcare industry: A structural equation model International journal of medical informatics, 76(1), 66-77.

Yewubedar Getachew (2018), Assessment of prospects and challenges of interest free banking in Ethiopia in the case of commercial bank of Ethiopia, north Addis district

Zhao, A., Koenig-Lewis, N., Hanmer-Lloyd, S. \& Ward, P., (2010) Adoption of internet banking services in China: is it all about trust? International Journal of Bank Marketing, 28(1), 7-26

Zikmund, W. G., Babin, B. J., Carr, J. C. \& Griffin, M. (2010) Business Research Methods (8thed) New Delhi: McMillan Publishers 